'[This] book is the first of its kind in Arabic sociolinguistics. It will set the standard for the field with its rich insights, brilliant range, and copious examples that make the subject come alive. I have no doubt whatsoever that this book will quickly emerge as the primary text on any course on Arabic in the social world.'

Yasir Suleiman, Director, Centre of Middle Eastern and Islamic Studies, University of Cambridge

'A useful new text book on Arabic sociolinguistics ... It presents a good overview of the literature ... and will teach students to look at Arabic language habits as phenomena, and not only as objects of normative discussion.'

Maartten Kossmann, Leiden, Fournal of Arabic Linguistics

'Arabic Sociolinguistics offers a new perspective on language variation and change, and makes it clear that language variation in the Arab world is undoubtedly different from that in the West. With a readable style, the book addresses the very complex diglossic situation in the Arab world with concrete examples resulting from interesting case studies that challenge the findings of recent studies on different sociolinguistic issues ... We highly recommend this book to all readers who wish to gain a better understanding of Arabic and the Arab world.'

Radia Benzehra and Don R. McCreary, University of Georgia, Fournal of Sociolinguistics

'For those interested in the Arab situation from a sociolinguistic point of view, it seems indispensable. The enthusiasm of the author and the abundant and insightful examples make this a good book to be discovered by readers of traditional introductions into sociolinguistics, which, so this book demonstrates, have as their point of departure a western way of looking at things. For many readers, a renewed acquaintance with sociolinguistics will arise after reading it. The book thus calls for more descriptions of language variation situations that are not western.'

Dick Smakman, University of Leiden, Historical Sociolinguistics and Sociohistorical Linguistics 
'This is an excellent effort in linguistic data collection and analysis and is a remarkable addition to sociolinguistics and indeed to the phenomenology of Arabic language and its reform; no library should be without it.'

Amidu Olalekan Sanni, Lagos State University, British Fournal

of Middle Eastern Studies

'This volume represents a welcome addition to the body of work on sociolinguistics, and specifically on Arabic sociolinguistics. While this book is a significant contribution to the field of sociolinguistic analysis, its true strength is its value to students interested in pursuing research associated with the Arab world. It will draw their attention to certain sociohistorical, cultural, and political aspects and their intertwining with the different linguistic features in the Arab world.'

Aleya Rouchdy, Wayne State University, Language in Society

'Bassiouney's book not only introduces various theoretical approaches, but also presents empirical data in order to illustrate the usefulness and limitations of these approaches.'

Muhammad Amara, Beit Berl Academic College, Language Policy 


\section{Arabic Sociolinguistics}

\section{Second edition}

Reem Bassiouney 
Edinburgh University Press is one of the leading university presses in the UK. We publish academic books and journals in our selected subject areas across the humanities and social sciences, combining cutting-edge scholarship with high editorial and production values to produce academic works of lasting importance. For more information visit our website: edinburghuniversitypress.com

(C) Reem Bassiouney, 2020

First edition published 2009

Edinburgh University Press Ltd

The Tun - Holyrood Road

12 (2f) Jackson's Entry

Edinburgh EH8 8PJ

Typeset in 11/13pt Ehrhardt by Servis Filmsetting Ltd, Stockport, Cheshire, and printed and bound in Great Britain

A CIP record for this book is available from the British Library

ISBN 9781474457330 (hardback)

ISBN 9781474457347 (paperback)

ISBN 9781474457361 (webready PDF)

ISBN 9781474457354 (epub)

The right of Reem Bassiouney to be identified as author of this work has been asserted in accordance with the Copyright, Designs and Patents Act 1988 and the Copyright and Related Rights Regulations 2003 (SI No. 2498). 